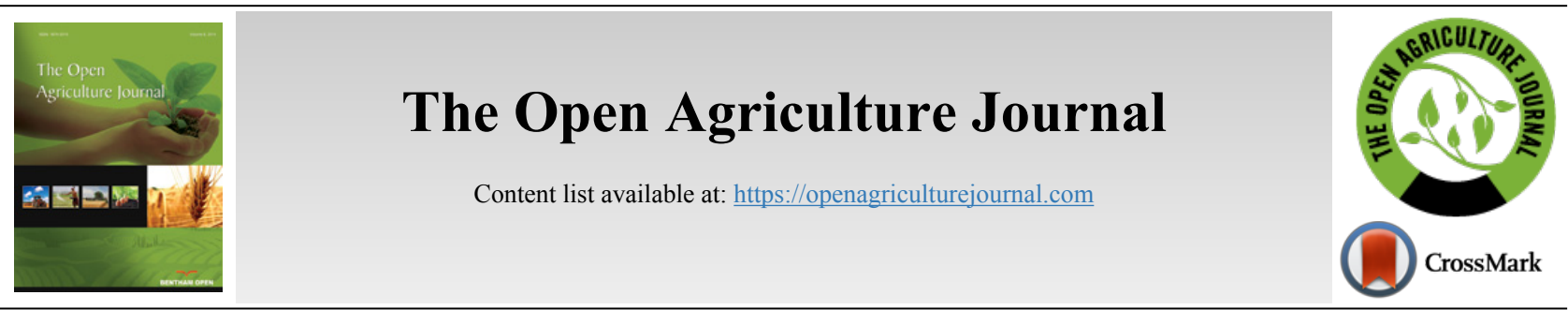

RESEARCH ARTICLE

\title{
International Aid for Agricultural Development of Timor-Leste
}

Hyejin Lee ${ }^{1, *}$

${ }^{I}$ Institute for International Development Cooperation, Konkuk University, Seoul, South Korea

\section{Abstract: \\ Background:}

The Democratic Republic of Timor-Leste is the newest nation in the 21 st century, which became independent in 2002 . Yet continued violent tensions kept the country from stabilizing its sociopolitical situations and it remains as a least developed country with many challenging issues, including food/nutrition insecurity. The international community has been supporting Timor-Leste to ameliorate it by aiding the agricultural development of the country.

\section{Objective:}

The objective of this study is to examine the aid profile of the donors for Timorese agricultural development. The findings of the study intend to provide the Timorese government and donors with a useful dialogue point for more efficient collaboration.

Methods:

The aid data reported to the Creditor Reporting System are sorted for the profile examination. The analysis is based on the aid disbursement between 2002 and 2019.

Results:

Australia was the largest donor, mostly shaping the agricultural aid profile of the donors. Japan, USA, and New Zealand were the major donors in that order, following Australia. Yet, their prioritized sub-sectors or interests appeared to vary; Australia prioritized strengthening Timorese seed systems and focused on nutrition-sensitive agriculture, Japan emphasized rice production, USA was mainly interested in cash/horticultural crops value chains, and New Zealand invested mainly in agricultural cooperatives. Of the multilateral organizations, the European Union was the principal donor.

\section{Conclusion:}

The Timorese government and donors may need a strategic collaboration to utilize available resources more efficiently as its food/nutrition insecurity is rooted in complex issues and improving it also hinges on development of other sectors.

Keywords: Agriculture, Food security, Nutrition security, Official development assistance, Timor-Leste, Nutrition.

\begin{tabular}{|l|l|l|r|}
\hline Article History & Received: April 16, 2021 & Revised: August 06, 2021 & Accepted: August 20, 2021
\end{tabular}

\section{INTRODUCTION}

The Democratic Republic of Timor-Leste, located between Indonesia and Australia, is the newest nation in the $21^{\text {st }}$ century. It is a small country with a population of 1.3 million, which became independent in 2002 after four centuries of Portuguese colonization, 24 years of Indonesian occupation and two years of the United Nations' (UN) administration [1, 2]. However, the absence of secure governance and institu-

\footnotetext{
* Address correspondence to this author at the Institute for International Development Cooperation, Konkuk University, Seoul, South Korea;
}

E-mail: hyejinlee@konkuk.ac.kr tions with unresolved political divisions led to civil crises in 2006 and the continued violent tensions prevented Timor-Leste from stabilizing its sociopolitical situations [2]. Currently, Timor-Leste is classified as a least developed country by the UN criteria and approximately $70 \%$ of its population live in rural areas, engaged in subsistence farming with few alternative income sources $[2,3]$. While the livelihood of most Timorese depends on agriculture, the economies of the country rely on revenues from petroleum. The petroleum revenues are absorbed into the Petroleum Fund, which has been the key source of the government budget since its establishment in $2005[4,5]$. Yet, the petroleum-based economies generate few 
viable employment options for the large proportion of the unskilled youth. In addition, the petroleum is estimated to be depleted earlier than predicted and management of the fund is criticized as unsustainable $[4,5]$. Thus, the heavy reliance on petroleum has the potential to push the country into fragile situations again.

The government of Timor-Leste, at present, focuses on transitioning from post-conflict recovery to long-term social stability [2]. In doing so, the government outlines its 20 -year development vision in the Strategic Development Plan 2011-2030 (SDP), and it identifies agriculture, the backbone of the Timorese livelihood, as a key area for economic development [6]. The government separately released policy documents related to agricultural development, such as the Ministry of Agriculture and Fisheries (MAF) Strategic Plan 2014-2020 and the Agriculture Policy and Strategic Framework 2017 for improved food/nutrition security. The current underdevelopment of its agricultural sectors is reflected on various food-security indices as well; the 2020 global hunger index estimates its level of hunger as 'alarming', ranking the country $106^{\text {th }}$ out of 107 countries reviewed [7]; its prevalence of undernourishment is assessed $31 \%$ whereas the world average is $9 \%$ during the period of 2017-2019 [8].

The crops mainly cultivated in the country are rice, maize, cassava, and coffee [6]. Of the key crops, coffee makes the largest contribution to the revenue. In 2019, it accounted for $17 \%$ of the total export, most of which was imported to Indonesia, Canada, and USA. If petroleum is excluded, coffee can account for approximately $80 \%$ of the non-oil export of the country $[6,9]$. However, the productivity and quality of its coffee are considered low. The average production of Timorese coffee in Green Bean Equivalent is estimated 195-204 kg/ha while the global average is $743 \mathrm{~kg} / \mathrm{ha}$. And Timorese coffee claims $0.1 \%$ of the global market due in part to quality issues $[1,10]$. Other major crops, cassava, maize, and rice are cultivated mostly at a subsistence level and their productivity is also deemed low with high post-harvest losses. For instance, with maize, it is estimated that $50 \%$ of the harvest is consumed at a household level, 20\% is used for animal feed or sold and the remaining $30 \%$ is lost during storage [11]. The causes of the weak status of Timorese agriculture are complex and multidimensional, involving a high poverty level, little existence of relevant infrastructure, low access to inputs and credits, complicated land titles, among others [12]. Despite those issues, improving agriculture is essential in both economic and food/nutrition security terms, given the heavy reliance of the Timorese on agriculture. The sector, nonetheless, receives around $2 \%$ of the state annual budget, and for the year 2020, the proposed allocation to MAF was 21.6 million $[13,14]$. In fact, a study indicates that the budget allocated to MAF is shrinking in real terms, adjusted for inflation over the past decade [15].

In line with the budget for development, the Timorese government recognizes that international support via foreign aid from bilateral donors, multilateral agencies, and non-profit organizations is vital to meet its development needs [16, 17]. Since its independence, the country has received an annual average of USD 197.4 million from the Organisation for Economic Co-operation and Development (OECD) Development Assistance Committee (DAC) members [18]. Or the net Official Development Assistance (ODA) that TimorLeste received as $\%$ of the Gross National Income (GNI) ranges between $28.8 \%$ in 2002 to $8.7 \%$ in 2019 [19]. This is not an insignificant amount, considering the size of the national budget. However, details of donor support for specific sectors, including agriculture, have little been explored, and such examinations could provide both the donors and the Timorese government with a useful dialogue point for future collaboration. With this background, the study intends to examine the agricultural aid profile of the donors and identify specific areas, in which the donors collectively and individually are interested. It should be mentioned that this study is not intended to assess aid effectiveness since it analyzes aid disbursement profiles. The remainder of the study is organized as follows; the second section briefly describes methods, the third presents findings from the profile analysis, and the last discusses and concludes.

\section{METHODS}

The study focuses on the OECD DAC donors since their ODA data are reported to the Creditor Reporting System (CRS) at a project level. The ODA data are extracted from the OECD Statistics and the time period is set between 2002 with independence of Timor-Leste and 2019, the latest year available at the moment. Values of aid disbursements as grant are measured in 2018 constant USD million, rounded off to the second decimal place. For the sectoral analysis, the data are sorted based on the CRS purpose codes. The CRS code consists of five digits; the first three digits of the five describe a corresponding upper-level sector, while the last two digits specify a sub-sector. And the most general sector code ends in the sequential number 10 . For instance, code 310 refers to the most general sector 'Agriculture, Forestry, Fishery' while codes 311, 312 and 313 refer to 'Agriculture', 'Forestry', and 'Fishery', respectively. For the sub-sectors of the three, for instance, the five-digit code 31161 describes 'food crop production' as one of the sub-sectors of the 311 'Agriculture' [20]. Where appropriate, either the three-digit or five-digit codes are adopted to sort the data.

\section{RESULTS}

\subsection{Bilateral Aid in Agriculture, Forestry, and Fishery}

Over the last two decades, Timor-Leste received a total USD 3.55 billion from the DAC donors with the annual average of USD 197.4 million (Table 1). In a relative term, the total amount disbursed to Timor-Leste accounts for $0.2 \%$ of the ODA that the DAC donors contributed to all developing countries during the study period. For the Timorese 310 (agriculture, forestry, and fishery, all combined), the DAC donors disbursed a total USD 216.5 million through 814 individual disbursements (Table 1). The largest support in absolute amount for the 310 came in 2017, accounting for about $12 \%$ of the total ODA in that year. Among the 14 donors that supported the 310 , Australia and Japan jointly explain over $60 \%$ of the total 310 disbursements, followed by USA and New Zealand (Table 1). In comparison, the five smallest donors collectively account for $1 \%$. The dominance of a few donors in the 310 suggests the aid profile of the sector is likely shaped by the priorities or preferences for specific aid modalities of the largest donors. 
Table 1. Aid disbursed by DAC donors and details of donor aid in agriculture, forestry, and fishery.

\begin{tabular}{|c|c|c|c|c|c|c|c|c|c|}
\hline Year & ODA \# Total & AFF \# ODA & $\%$ AFF & $\begin{array}{c}\text { No. of } \\
\text { AFF Aids } \\
\text { 登 } \\
\end{array}$ & AFF Donor & Amount & $\%$ of Donor & No. of Aids & Avg. § \\
\hline 2002 & 291.65 & 7.50 & 2.6 & 21 & Australia & 73.70 & 34.0 & 191 & 0.39 \\
\hline 2003 & 194.87 & 7.06 & 3.6 & 20 & Japan & 57.08 & 26.4 & 286 & 0.20 \\
\hline 2004 & 168.88 & 4.59 & 2.7 & 23 & USA & 32.53 & 15.0 & 101 & 0.32 \\
\hline 2005 & 202.46 & 5.26 & 2.6 & 27 & New Zealand & 21.43 & 9.9 & 32 & 0.67 \\
\hline 2006 & 208.23 & 4.38 & 2.1 & 22 & Korea & 9.53 & 4.4 & 87 & 0.11 \\
\hline 2007 & 242.25 & 4.42 & 1.8 & 32 & Portugal & 6.85 & 3.2 & 29 & 0.24 \\
\hline 2008 & 230.21 & 13.01 & 5.7 & 49 & Spain & 6.06 & 2.8 & 19 & 0.32 \\
\hline 2009 & 191.61 & 11.46 & 6.0 & 67 & Norway & 3.70 & 1.7 & 9 & 0.41 \\
\hline 2010 & 244.31 & 12.54 & 5.1 & 62 & Ireland & 3.30 & 1.5 & 24 & 0.14 \\
\hline 2011 & 211.22 & 15.01 & 7.1 & 47 & Canada & 1.65 & 0.8 & 15 & 0.11 \\
\hline 2012 & 183.14 & 13.90 & 7.6 & 51 & Germany & 0.36 & 0.2 & 11 & 0.03 \\
\hline 2013 & 176.80 & 17.25 & 9.8 & 60 & Finland & 0.10 & 0.0 ฯ & 3 & 0.03 \\
\hline 2014 & 171.63 & 13.15 & 7.7 & 66 & Belgium & 0.09 & 0.0 & 3 & 0.03 \\
\hline 2015 & 159.62 & 18.18 & 11.4 & 65 & Italy & 0.09 & 0.0 & 4 & 0.02 \\
\hline 2016 & 168.84 & 18.44 & 10.9 & 58 & Total & 216.48 & 100 & 814 & N/A \\
\hline 2017 & 165.91 & 19.54 & 11.8 & 46 & \multirow{4}{*}{\multicolumn{5}{|c|}{$\begin{array}{l}\text { \# ODA: Official Development Assistance, amount in } 2018 \text { constant USD million, AFF: } \\
\text { Agriculture, Forestry, Fishery, 业: Number of individual annual disbursements, § Averaged } \\
\text { with total amount and aid number on yearly basis, thus not reflect the whole disbursement of } \\
\text { a multi-year project, } \uparrow: \text { Due to rounding off }\end{array}$}} \\
\hline 2018 & 157.86 & 14.35 & 9.1 & 51 & & & & & \\
\hline 2019 & 184.25 & 16.46 & 8.9 & 47 & & & & & \\
\hline Total & 3553.76 & 216.48 & 6.1 & 814 & & & & & \\
\hline
\end{tabular}

Within the 310 , the 311 (agriculture) is by far the most supported sector, $86 \%$ in amount and $82 \%$ in aid number (Table 2). The 312 (forestry) and 313 (fishery) share each 6\% and $8 \%$ in the total amount. Across the sub-sectors of the 310 , 24 of them are supported, of which the 31120 (agricultural development such as farm development) receives the largest amount or $43 \%$. Following the 31120, the 31110 (agricultural policy and administrative management) receives $10 \%$, and the 31140 (agricultural water resources such as irrigation) $9 \%$. Excluding the 311 and within the 312, the donors mainly support the 31210 (forestry policy and administrative management) whereas within the 313 , the 31310 (fishery policy and administrative management) and 31320 (fishery development such as aquaculture) are similarly aided (Table 2). Despite the fact that the country has $706 \mathrm{~km}$ of the coastal line and mostly consists of mountainous terrain [21], the donors appear less interested in fishery and forestry. In sum, the donors prioritize development in agriculture with some emphasis on improving relevant policies and administrative capacity. This may be due partly to that the overall institutional capacity of the country is assessed weak to deliver public services and implement relevant policies [2, 17, 22].

Table 2. Aid allocated to each agriculture, forestry, and fishery.

\begin{tabular}{|c|c|c|c|c|c|c|c|c|}
\hline Sector 311§ & Amount & No. of Aid & $\begin{array}{c}\text { Sector 311 } \\
\text { (Cont.) }\end{array}$ & Amount & No. of Aid & Sector 312 & Amount & No. of Aid \\
\hline 31120 & 91.99 & 196 & 31191 & 1.43 & 5 & 31210 & 11.49 & 57 \\
\hline 31110 & 21.05 & 191 & 31193 & 1.23 & 4 & 31220 & 0.31 & 10 \\
\hline 31140 & 20.36 & 25 & 31181 & 1.04 & 22 & 31281 & 0.05 & 1 \\
\hline 31161 & 11.97 & 48 & 31195 & 0.92 & 29 & 312 Total & 11.85 & 68 \\
\hline 31182 & 11.22 & 41 & 31163 & 0.55 & 8 & Sector 313 & Amount & No. of aid \\
\hline 31194 & 10.96 & 17 & 31166 & 0.46 & 13 & 31320 & 10.19 & 39 \\
\hline 31192 & 5.02 & 12 & 31150 & 0.17 & 4 & 31310 & 8.04 & 38 \\
\hline 31130 & 4.87 & 42 & 31165 & 0.10 & 3 & 31381 & 0.02 & 2 \\
\hline 31162 & 3.03 & 6 & 311 Total & 186.36 & 666 & 31391 & 0.02 & 1 \\
\hline \#: amount in 2018 constant USD million & & & 313 Total & 18.26 & 80 \\
\hline
\end{tabular}

$\S:$ In the order of amount, 311-Agriculture, 312-Forestry, 313-Fishery, 31110-Agricultural policy and administrative management, 31120-

Agricultural development, 31130-Agricultural land resources, 31140-Agricultural water resources, 31150-Agricultural inputs, 31161-Food crop production, 31162-Industrial crops/export crops, 31163-Livestock, 31165-Agricultural alternative development, 31166-Agricultural extension, 31181-Agricultural education/training, 31182-Agricultural research, 31191-Agricultural services, 31192-Plant and post-harvest protection and pest control, 31193-Agricultural financial services, 31194-Agricultural co-operatives, 31195-Livestock/veterinary services, 31210-Forestry policy and administrative management, 31220-Forestry development, 31282-Forestry research, 31310-Fishing policy and administrative management, 31320Fishery development, 31381-Fishery education/training, 31391-Fishery services 
The top donors for each the 311,312 and 313 vary: Australia for the 311, Japan for the 312, and Korea for the 313 (Table 3). The overall largest donor, Australia exclusively supports the 311; the amount Australia disbursed to the 311 accounts for $98 \%$ of its total 310 ODA (Table 4). Of the 311 sub-sectors, the 31120 (agricultural development) receives the largest amount, followed by the 31182 (agricultural research), and 31110 (agricultural policy and administrative management). The Australian aid documents state that Australia identified seed shortages as an urgent issue for Timorese food production. Accordingly, it targeted at increasing the distribution of high-yielding seeds for staple food crops and subsequently improving productivity and produce marketability [16, 22, 23]. Based on its strategic priorities in the 311 , Australia disbursed over $40 \%$ of its total disbursement to the multi-year project called 'Seeds of Life'; 32 individual disbursements are associated with the project from 2002 through 2016 and receive approximately USD 30 million. Initiated in 2001, the project invested in developing high-yielding crop varieties and facilitating community-based seed systems [24]. At the national level, the project is deemed to have assisted the Timorese government in setting up the national seed system, for which MAF took full responsibility in 2015 [25]. Nonetheless, the project document notes the improved productivity in the basic food crop alone might not be sufficient to address the country's food/nutrition insecurity. Thus, the following Australian project, called TOMAK includes 'Nutrition Sensitive Agriculture' approaches, being planned to run from 2016 through 2021 [26]. Outside the direct support in agricultural production and value chain development, Australia invests a substantial amount in agricultural research, mostly through technical assistance (Table 4). The majority of the 31182 (agricultural research) dusbursement is directed to the projects with the Australian Centre for International Agricultural Research.

Table 3. Top donors for each agriculture, forestry, and fishery

\begin{tabular}{|c|c|c|c|c|c|}
\hline Sector 311 \# & Amount & Sector 312 & Amount & Sector 313 & Amount \\
\hline Australia & 72.16 & Japan & 10.50 & Korea & 6.56 \\
\hline Japan & 45.75 & Canada & 1.04 & New Zealand & 4.18 \\
\hline United States & 32.50 & Korea & 0.17 & Norway & 3.70 \\
\hline New Zealand & 17.25 & Portugal & 0.06 & Australia & 1.49 \\
\hline Portugal & 6.79 & Australia & 0.06 & Spain & 1.42 \\
\hline
\end{tabular}

\#: 311-Agriculture, 312, Forestry, 313-Fishery, amount in 2018 constant USD million

Table 4. Aid details of five top donors.

\begin{tabular}{|c|c|c|c|c|c|c|c|c|c|c|c|}
\hline \multicolumn{3}{|c|}{ Australia } & \multicolumn{3}{|c|}{ Japan } & \multicolumn{3}{|c|}{ Korea } & \multicolumn{3}{|c|}{ New Zealand } \\
\hline $311 \S$ & Amount\# & $\%$ amount & 311 & Amount & $\%$ amount & 311 & Amount & $\%$ amount & 311 & Amount & $\%$ amount \\
\hline 31110 & 7.82 & 10.6 & 31110 & 5.55 & 9.7 & 31110 & 0.36 & 3.8 & 31120 & 0.75 & 3.5 \\
\hline 31120 & 42.08 & 57.1 & 31120 & 13.95 & 24.4 & 31120 & 0.50 & 5.2 & 31161 & 0.80 & 3.7 \\
\hline 31130 & 0.01 & 0.0 & 31130 & 3.37 & 5.9 & 31150 & 0.12 & 1.3 & 31162 & 2.95 & 13.8 \\
\hline 31140 & 0.00 & 0.0 & 31140 & 19.91 & 34.9 & 31161 & 0.05 & 0.5 & 31191 & 0.85 & 4.0 \\
\hline 31161 & 4.83 & 6.6 & 31150 & 0.05 & 0.1 & 31162 & 0.09 & 0.9 & 31193 & 1.16 & 5.4 \\
\hline 31163 & 0.00 & 0.0 & 31161 & 2.55 & 4.5 & 31163 & 0.54 & 5.6 & 31194 & 10.75 & 50.2 \\
\hline 31166 & 0.13 & 0.2 & 31163 & 0.01 & 0.0 & 31166 & 0.32 & 3.4 & 313 & Amount & $\%$ amount \\
\hline 31181 & 0.30 & 0.4 & 31181 & 0.08 & 0.1 & 31181 & 0.52 & 5.4 & 31320 & 4.18 & 19.5 \\
\hline 31182 & 11.13 & 15.1 & 31191 & 0.22 & 0.4 & 31182 & 0.02 & 0.2 & Total & 21.43 & 100 \\
\hline 31192 & 5.02 & 6.8 & 31195 & 0.06 & 0.1 & 31191 & 0.02 & 0.2 & \multirow{2}{*}{\multicolumn{3}{|c|}{ United States }} \\
\hline 31195 & 0.84 & 1.1 & 312 & Amount & $\%$ amount & 31193 & 0.06 & 0.7 & & & \\
\hline 312 & Amount & \% amount & 31210 & 10.37 & \begin{tabular}{|l|}
18.2 \\
\end{tabular} & 31194 & 0.21 & 2.2 & 311 & Amount & $\%$ amount \\
\hline 31220 & 0.01 & 0.0 & 31220 & 0.13 & 0.2 & 312 & Amount & $\%$ amount & 31110 & 6.40 & 19.7 \\
\hline 31281 & 0.05 & 0.1 & 313 & Amount & $\%$ amount & 31220 & 0.17 & 1.8 & 31120 & 26.04 & 80.0 \\
\hline 313 & Amount & $\%$ amount & 31310 & 0.66 & \begin{tabular}{|l|}
1.2 \\
\end{tabular} & 313 & Amount & $\%$ amount & 31182 & 0.07 & 0.2 \\
\hline 31310 & 0.03 & 0.0 & 31320 & 0.17 & 0.3 & 31310 & 6.20 & 65.0 & 312 & Amount & $\%$ amount \\
\hline 31320 & 1.46 & 2.0 & \multirow{3}{*}{ Total } & \multirow{3}{*}{57.08} & \multirow{3}{*}{100} & 31320 & 0.33 & 3.4 & 31210 & 0.03 & 0.1 \\
\hline 31381 & 0.00 & 0.0 & & & & 31381 & 0.02 & 0.2 & \multirow{3}{*}{ Total } & \multirow{3}{*}{32.53} & \multirow{3}{*}{100} \\
\hline Total & 73.70 & 100 & & & & 31391 & 0.02 & 0.2 & & & \\
\hline \#: amoun & 2018 const & nt USD millio & & & & Total & 9.53 & 100 & & & \\
\hline
\end{tabular}


(Table $\square$ ) contd....

\begin{tabular}{|c|c|c|c|c|c|c|c|c|c|c|c|}
\hline \multicolumn{3}{|c|}{ Australia } & \multicolumn{3}{|c|}{ Japan } & \multicolumn{3}{|c|}{ Korea } & \multicolumn{3}{|c|}{ New Zealand } \\
\hline $311 \S$ & Amount\# & $\%$ amount & 311 & Amount & $\%$ amount & 311 & Amount & $\%$ amount & 311 & Amount & $\%$ amount \\
\hline \multicolumn{12}{|c|}{$\begin{array}{l}\text { \$: 311-Agriculture, 312-Forestry, 313-Fishery, 31110-Agricultural policy and administrative management, 31120-Agricultural development, 31130- } \\
\text { Agricultural land resources, 31140-Agricultural water resources, 31150-Agricultural inputs, 31161-Food crop production, 31162-Industrial } \\
\text { crops/export crops, 31163-Livestock, 31165-Agricultural alternative development, 31166-Agricultural extension, 31181-Agricultural } \\
\text { education/training, 31182-Agricultural research, 31191-Agricultural services, 31192-Plant and post-harvest protection and pest control, 31193- } \\
\text { Agricultural financial services, 31194-Agricultural co-operatives, 31195-Livestock/veterinary services, 31210-Forestry policy and administrative } \\
\text { management, 31220-Forestry development, 31282-Forestry research, 31310-Fishing policy and administrative management, 31320-Fishery } \\
\text { development, 31381-Fishery education/training, 31391-Fishery services }\end{array}$} \\
\hline
\end{tabular}

Japan, the second largest donor, also concentrates its support on the 311 or $80 \%$ of its total aid (Table 4). In particular, the 31140 (agricultural water resources) receives the largest amount followed by the 31120 (agricultural development). Total 17 disbursements by Japan are reported as the 31140 and the majority of them are linked to rehabilitation or construction of irrigation. Japanese interests in water resources and agricultural infrastructure are clearly indicated in its ODA document and directly related to its prioritized crop, rice [27]. Rice, the staple food crop of Timor-Leste, provides the Timorese with up to $42 \%$ of the average calories required [28]. However, due to the limited irrigated areas and low productivity in rice, a large amount of rice is imported from China, Indonesia, Pakistan, Thailand, and Vietnam. In 2019, Timor-Leste imported rice worth USD 12.9 million, accounting for $2.4 \%$ of the country's total import [9]. Notably, Japan focuses on technical cooperation. Of 204 aids for the 311, 166 aids are recorded as 'Technical Cooperation Aggregated Activities' with the average per-aid disbursement of USD 0.14 million. This average is smaller than the overall Japanese peraid disbursement or USD 0.2 million. However, reporting the disbursements under technical cooperation limits further examination of them because it does not provide detailed information. In sum, it seems that Japanese aid in the 311 prioritizes improvement in rice production and irrigation systems with provision of relevant technical assistance.

The third largest donor to the 311 is the USA, which focuses particularly on the 31120 (Table 4). Among the aids categorized as the 31120, a multi-year project called 'Consolidation of Cooperative Agribusiness Recovery (COCAR)' receives 31\% (approximately USD 10 million) of the total amount. The project aimed to raise agricultural productivity, especially for coffee and cocoa through crop rehabilitation, crop diversification and intercropping, strengthen linkages between farmers and markets and increase farm household incomes [30]. Another notable project from USA is AVANSA, which received $21 \%$ of the total amount (USD 6.8 million) disbursed between 2016 and 2019. This project targeted to reinforce the Timorese horticultural value chain by increasing horticultural crop production, linking farm households to markets, and promoting relevant policies [31]. Different from COCAR, the majority of the disbursements to AVANSA is reported as the 31110 (agricultural policy and administrative management). However, it should be noted that as AVANSA ended at the end of 2020 with the total budget of USD 19.2 million, its specific budget allocations are not fully available at the moment. As stated in the US Agency for International Development (USAID) 2001-2004 Transition Strategy Timor-Leste, USA began supporting Timorese agriculture with its coffee, which accounts for around $80 \%$ of the country's non-oil export. Yet, the ODA data suggest the agricultural aid from USA gradually shifts from the coffee value chain to the horticultural crop value chain. This shift is also indicated in the recent USAID documents, which emphasize nutrition sensitive agriculture and food security $[2$, 5]. Furthermore, the Timorese coffee industry likely need less external support than other crops because of the strong presence of the Timorese coffee cooperative, or Cooperativa Café Timor. It is the largest cooperative in Timor-Leste that exercises close to monopolic power with provision of some social services such as basic medical cares under the Café Clinics [29].

Following USA, New Zealand invests over $80 \%$ of its aid in the 311. Its focused sub-sector is the 31194 (agricultural cooperatives including farmers' organizations) (Table 4). In supporting and improving Timorese agricultural cooperatives, New Zealand utilizes two venues; one is co-sponsoring USA's COCAR and the other is funding a project called 'IMPACT (Improving Marketing and Production through Agricultural Cooperatives in Timor-Leste)' implemented by an NGO, OXFAM [31]. Until 2011, New Zealand appeared little visible in the 310 because it disbursed only 3 aids between 2002 and 2010. Yet, with its significant increase in supporting the sector, New Zealand seems to emphasize improving agricultural cooperatives under its stated priority: increase economic and food security benefits from agriculture [32]. Notably though, New Zealand has the largest average per-aid disbursement among the principal donors, due to the smallest aid number. In comparison, Japan carries out its support nine times larger in aid number with three times larger in aid amount than New Zealand (Table 1).

In the 312 (forestry), the majority of the aid comes from Japan, which accounts for $89 \%$ of the total amount in the 312 (Table 3). To support Timorese forestry, Japan made 51 disbursements, 50 of which are technical cooperation in the 31210 (forestry policy and administrative management). In the 313 (fishery), the principal donors are Korea, New Zealand, and Norway (Table 3). Korea, the largest donor in the 313, disbursed $95 \%$ of its total 313 support to one multi-year project from 2014 to 2019, which is titled 'Establishment of Education and Training Center for Fishing Industry of Timor-Leste'. Likewise, New Zealand heavily invested in one multi-year project between 2013 and 2019 under the umbrella of 'Aquaculture Development in Timor-Leste'. Norway that supports only the 313 disburses most of its ODA to the 31320 (fishery development) via two venues, 'Fishery Cooperation in Timor-Leste' and 'Supporting Inland Fishery for Women in Timor-Leste'. 
Table 5. Multilateral aid for agriculture, forestry, and fishery.

\begin{tabular}{|c|c|c|c|c|c|}
\hline EU $\S$ & Amount \# & IDA $\S$ & Amount & FAO $\S$ & Amount \\
\hline Sector $311 \%$ & 13.65 & Sector 311 & 1.48 & Sector 311 & 0.30 \\
\hline 31110 & 0.08 & 31120 & 1.48 & 31110 & 0.15 \\
\hline 31120 & 12.18 & Total & 1.48 & 31120 & 0.02 \\
\hline 31163 & 0.02 & \multirow{2}{*}{ UNDP $\S$} & \multirow{2}{*}{ Amount } & 31130 & 0.02 \\
\hline 31181 & 1.38 & & & 31181 & 0.08 \\
\hline Sector 312 & 6.11 & Sector 311 & 0.03 & 31192 & 0.04 \\
\hline 31220 & 6.03 & 31130 & 0.03 & Sector 312 & 0.08 \\
\hline 31261 & 0.09 & 31150 & $0.00 \int$ & 31210 & 0.08 \\
\hline Total & 19.76 & Total & 0.03 & 313 & 0.03 \\
\hline \multirow{2}{*}{\multicolumn{4}{|c|}{$\begin{array}{l}\text { \# Amount in } 2018 \text { constant USD million, § EU: European Union, FAO: Food and Agriculture } \\
\text { Organization, IDA: International Development Association, UNDP: UN Development Programme }\end{array}$}} & 31320 & 0.03 \\
\hline & & & & Total & 0.41 \\
\hline
\end{tabular}

\subsection{Multilateral Aid in Agriculture, Forestry, and Fishery}

The multilateral organizations do not particularly prioritize the 310 across the development sectors. During the study period, they disbursed total USD 766.5 million as grant to the 35 different sectors in Timor-Leste, and the 311, 312 and 313 jointly account for only $3 \%$ of the total, or USD 21.7 million. Across the sectors, the 210 (transport and storage), 122 (basic health), 151 (governance and civil society general), and 430 (other multisector) are the highly supported ones, together explaining $63 \%$ of the total amount. The multilateral organizations thus appear to lean towards public-service sectors. While the multilateral grant for the 310 is small in absolute amount, the 311 is dominant over the 312 and 313 .

Four multilateral organizations support the 310: European Union (EU), Food and Agriculture Organization (FAO), International Development Association (IDA) and UN Development Programme (UNDP) (Table 5). Yet, EU contributes over $90 \%$ of the total 310 aid, remotely followed by IDA, FAO, and UNDP in that order. The European Union mainly supports the $311(69 \%)$ and the $312(31 \%)$ with a particular interest in two sub-sectors, the 31120 (agricultural development) and 31220 (forest development). Among the 311 aids made by EU, a multi-year project from 2012 through 2016 receives about $50 \%$ of the total $\mathrm{EU}$ aid for the strengthened Timorese agricultural extension systems. Different from EU, which carries out all project-type aids, IDA implements its ODA as sector-specific budget support and FAO appears more interested in technical assistance including training, and research-relevant activities. Overall, EU shapes the aid profile of the 310 among the multilateral organizations and appears to emphasize the agricultural extension systems.

\section{DISCUSSION}

Of the bilateral donors, Australia exercises the largest influence in shaping the bilateral aid profile for the sector 310 . The donor focuses on the sector 311 mainly through the two multi-year projects for the food crop seed system, and nutrition-centered production and consumption. While concentrating their aids on the 311 , other largest donors, Japan,
USA, and New Zealand show all different interests; Japan emphasizes irrigation and technical cooperation revolving around rice, USA moves from the coffee to the horticultural crop value chain, and New Zealand prioritizes fostering agricultural cooperatives. The multilateral aid profile in the 310, exclusively molded by EU, shows EU appears highly interested in promoting the Timorese agricultural extension systems. Yet it need be mentioned that the ODA loans by the regional development banks such as the Asian Development Bank and World Bank could have made a difference if they were considered, since this study deals with only ODA grants.

The donor supports are critical to improve Timorese food/nutrition insecurity, but it is rooted in complicated issues, ranging from its low-input low-output production system, limited access to credits, unresolved land titles, vulnerable food supply systems to global food prices to climate variations. In addition, enhancing food/nutrition security partly hinges on the development of other segments such as basic infrastructure for transport and electricity. Therefore, the donors and Timorese government need to promote strategic collaborations to mobilize and allocate available resources most effectively. In doing so, the donors could split up the roles based on their comparative advantages and aid priorities. For instance, Australia and USA can keep focusing on the nutrition-sensitive agriculture, Japan on the rice production, New Zealand on the agricultural cooperatives and EU on the extension system whereas all other small donors work with the leading donors to bolster these key areas for facilitated agricultural development.

Simultaneously, the Timorese government first could prioritize and specify where international support is most needed. Currently, the Timorese document 'Foreign Aid Policy' does not sufficiently clarify them, rather the document covers most of the development sectors for international aid. Second, the government needs to increase its budget allocation to agricultural development. The public spending on agriculture is estimated very low with even a decreasing trend [4]. After all, secured food situations are the government's responsibility for its people. Third, the government could make significant efforts to provide accurate data reflecting the 
farming realities at a local level [33]. Those data sets are often required to lead development partners to better design and implement their projects relevant to food/nutrition security.

\section{CONCLUSION}

Timor-Leste has a turbulent history, complicated present and challenging future for its development [34]. Across the multiple development issues the country faces, food/nutrition insecurity is probably the most fundamental one that needs to be urgently addressed. While the Timorese government and donors need strategically strengthened partnerships to better use available resources, the government can mobilize its own resources to support agricultural sectors and specify its priorities to lead the donors more effectively.

While the findings of the study are valid, limitations exist. The sector 430 (other multisector) includes several sub-sectors related to food/nutrition security, such as the 43040 (rural development), but it is difficult to dissect project components directly associated with development in agriculture, forestry, and fishery. Other limitations include a relative shortage of literature, and exclusion of non-DAC donors such as China, which are not obliged to share aid data. For future research, additional analyses with non-DAC donors could provide a more comprehensive understanding of the international aid to Timor-Leste.

\section{ETHICS APPROVAL AND CONSENT TO PARTI- CIPATE}

Not applicable.

\section{HUMAN AND ANIMAL RIGHTS}

Not applicable.

\section{CONSENT FOR PUBLICATION}

Not applicable.

\section{AVAILABILITY OF DATA AND MATERIALS}

Not applicable.

\section{FUNDING}

None.

\section{CONFLICT OF INTEREST}

The author declares no conflict of interest, financial or otherwise.

\section{ACKNOWLEDGEMENTS}

Declared none.

\section{REFERENCES}

[1] Khamis S. Timor-Leste coffee: Marketing the "Golden prince" in postcrisis conditions. Food Cult Soc 2015; 18(3): 481-500.

[http://dx.doi.org/10.1080/15528014.2015.1043109]

[2] USAID. Timor-leste country development cooperation strategy. 2013-2018.

[3] USCTAD

Avaiable

from: https://unctad.org/topic/least-developed-countries/list

[4] Doraisami A. The timor leste petroleum fund, veterans and white elephants: Fostering intergenerational equity? Resour Policy 2018; 58 : 250-6.

[http://dx.doi.org/10.1016/j.resourpol.2018.05.013]

[5] USAID. Timor-leste country development cooperation strategy. 2020-2025.

[6] GOTL (Government of Timor-Leste) strategic development plan. Strategic Development Plan. Dili, Timor-Leste 2011-2030.

[7] von Grebmer K, Bernstein J, Alders R, et al. Global hunger index: One decade to zero hunger: Linking health and sustainable food systems. 2020. Bonn: Welthungerhilfe; and Dublin: Concern Worldwide

[8] FAO. Sustainable development goals: Indicator 2.1.1 - Prevalence of undernourishment Available at: http://www.fao.org/sustainable-development-goals/indicators/211/en/

[9] OEC. 2020. Available at: https://oec.world/en/profile/country/tls

[10] FAO statistics. Available at: http://www.fao.org/faostat/en/\#data

[11] TOMAK. Potential for improving on-farm productivity of selected agricultural and livestock enterprises. Technical Report 22016.

[12] Asian Development Bank. Growing the non-oil economy a private sector assessment for timor-leste. Manila, Philippines 2015.

[13] Neves, Guteriano Nicolau S. The paradox of aid in Timor-Leste In: Cooperação Internacional ea Construção do Estado no Timor-Leste seminar. 2006; pp. 25-8.

[14] Republic of Timor-Leste. State Budget. Dili Timor-Leste: Budget Overview Book 12020

[15] OXFAM. Agriculture Assessment OXFAM in Timor-Leste. 2020.

[16] AusAid. Australia-Timor-Leste Country Strategy 2009 to 2014. Canberra: Australian Government 2014.

[17] GOTL (Government of Timor-Leste). Timor-Leste Strategic Development Plan 2011-2030: version submitted to the national parliament. Dili: Government of Timor-Leste 2011.

[18] OECD statistics. Available at: https://stats.oecd.org/\#

[19] World Bank. Available at https://data.worldbank.org/indicator/DT.ODA.ODAT.GN.ZS

[20] OECD purpose codes: Sector classification Available at: http://www.oecd.org

[21] CIA. The World Fact Book Available from: https://www.cia.gov/the-world-factbook/countries/timor-leste/

[22] Australian Government DFAT. Aid Investment Plan. Canberra: Timor-Leste 2015/16 to 2018/19 Australian Government 2015/16.

[23] AusAid (Australian Agency for International Development) AuditorGeneral Audit report for 2003-2004 No 20: Performance audit Aid to East Timor 2003.

[24] ACIAR (Australian Centre for International Agricultural Research) Final Report: Seeds of Life 32016.

[25] Adam Smith International TOMAK. Agricultural Input Supply Strengthening 2018

[26] Adam Smith International TOMAK. Farming for Prosperity 2015.

[27] JICA. Japan International Cooperation Agency: Cooperation in TimorLeste 2019. Available at: http://www.jica.go.jp/easttimor/english/

[28] MAF (Ministry of Agriculture and Fisheries). Ministry of Agriculture and Fisheries Strategic Plan 2014-2020.

[29] USAID Consolidating cooperative agribusiness recovery in timorleste. Available at: https://www.usaid.gov/timor-leste/project-descriptions/consolidating-c ooperative-agribusiness-recovery-timor-leste

[30] USAID'S AVANSA Agrikultura project final report 2021. Available at: https://pdf.usaid.gov/pdf_docs/PA00XBPW.pdf

[31] OXFAM. $201 \overline{9}$. Available at: https://asia.oxfam.org/latest/blogs/timor-leste\%E2\%80\%99s-food-revo lution-remote-oecusse-capital-dili

[32] NZFAT (New Zealand Foreign Affairs and Trade) Timor-Leste. Available at: https://www.mfat.govt.nz/en/aid-and-development/our-aid-partnership s-in-south-east-asia/timor-leste/

[33] Moore A, Dormody T, VanLeeuwen D, Harder A. Agricultural sustainability of small-scale farms in Lacluta, Timor Leste. Int J Agric Sustain 2014; 12(2): 130-45.

[http://dx.doi.org/10.1080/14735903.2013.842341]

[34] Molyneux N. Seeds of life: Adapting for food security. Issues magazine. March 2011 Available at: http://www.issuesmagazine.com.au/article/issue-march-2011/seeds-lif e-adapting-food-security.html 